\title{
The implicit taxonomy of the equality jurisprudence of the UN Human Rights Committee
}

\author{
Niels Petersen ${ }^{\star}$ (i) \\ University of Münster, Schlossplatz 2, 48149 Münster, Germany \\ Email: niels.petersen@uni-muenster.de
}

\begin{abstract}
The article analyses the individual communications of the UN Human Rights Committee (HRC) on how the latter conceptualizes equality under the International Covenant on Civil and Political Rights (ICCPR). It finds an implicit taxonomy in the case law that is not reflected in the doctrinal formulae that the HRC applies. The argument proceeds in several steps: First, I argue that the concept of equality in human rights treaties depends heavily on its operationalization by courts and quasi-judicial bodies, like the HRC. Second, I analyse the doctrinal formulae that the HRC has developed in order to specify equality. I argue that the doctrine is rather inconsistent and does not give significant guidance for resolving actual cases. Third, I present the results of a systematic analysis of the case law of the HRC. The latter shows a rather stable pattern which is not reflected in the doctrinal formulae: The best predictor whether the HRC finds a violation of Article 26 ICCPR or another equality norm of the Convention is the existence of a suspect criterion on which the challenged distinction was based. There are only very few cases in which a violation is found in the absence of a suspect criterion. The majority of these cases arguably concern arbitrary state actions. At the same time, the HRC has only rarely held that a state has not violated an equality norm despite the existence of a suspect criterion.
\end{abstract}

Keywords: discrimination; equality; Human Rights Committee; ICCPR; suspect criterion

\section{Introduction}

Equality is a contested concept: Two individuals will never be equal in all respects so that we have to determine the dimensions to which equality should apply. This puzzle has often been addressed in the theoretical literature on equality and discrimination, ${ }^{1}$ but has received less attention in

${ }^{\star}$ The author is Professor of Law and Co-Director of the Institute for international and comparative public law at the University of Münster. I am very grateful for comments and suggestions of Jasmin Beck, Konstantin Chatziathansiou, Tainá Garcia Maia, Joanna Mrozinska, Shubhangi, and Helina Teka on earlier drafts of this article. The article is part of the research project 'Correcting Inequality through Law' that has received funding from the European Research Council (ERC) under the European Union's Horizon 2020 research and innovation programme (grant agreement No 817652).

${ }^{1}$ See, e.g., O. Fiss, 'Groups and the Equal Protection Clause', (1976) 5 Philosophy \& Public Affairs 107; P. Westen, 'The Empty Idea of Equality', (1982) 95 Harvard Law Review 537; K. Greenawalt, 'How Empty Is the Idea of Equality?', (1983) 83 Columbia Law Review 1167; L. Alexander, 'What Makes Wrongful Discrimination Wrong? - Biases, Preferences, Stereotypes, and Proxies', (1992) 141 University of Pennsylvania Law Review 149; C. R. Sunstein, 'The Anticaste Priniple', (1994) Michigan Law Review 2410; D. Hellman, When Is Discrimination Wrong? (2008); S. Moreau, 'What is Discrimination?', (2010) 38 Philosphy \& Public Affairs 143; T. Khaitan, A Theory of Discrimination Law (2015); S. Fredman, 'Substantive Equality Revisited', (2016) 14 International Journal of Constitutional Law 712; J. Waldron, One another's equals: The basis of human equality (2017).

(C) The Author(s), 2021. Published by Cambridge University Press. This is an Open Access article, distributed under the terms of the Creative Commons Attribution licence (http://creativecommons.org/licenses/by/4.0/), which permits unrestricted re-use, distribution, and reproduction in any medium, provided the original work is properly cited. 
international law scholarship. ${ }^{2}$ This contribution analyses how the HRC deals with this conundrum of equality. ${ }^{3}$ It looks at the doctrines that the HRC has developed in order to conceptualize equality - in particular in the context of Article 26 of the $\mathrm{ICCPR}^{4}$ - and shows that these doctrines are mostly empty: They do not help to explain the case law of the Committee. Nevertheless, if we analyse the case law in detail, we see that the HRC has developed an implicit taxonomy of dealing with equality cases that goes beyond the doctrinal formulae.

The argument consists of four parts. First, I will have a closer look at the conundrum of equality. I argue that equality is not a self-sufficient normative concept, but that its operationalization is dependent on external normative standards. In judicial practice, we find roughly two approaches to conceptualize equality - the interpretation of equality as a non-discrimination guarantee, protecting specific vulnerable groups, and a formal interpretation of equality as a consistency requirement. Section 3 analyses the doctrinal conceptualizations of equality by the HRC. It shows that the doctrines developed by the Committee are so vague that they do not offer any support in resolving cases and that they are applied inconsistently.

Section 4 is the core of the argument. It consists of a detailed analysis of the case law of the HRC. For this purpose, I analysed all individual communications dealing with one of the equality norms in the ICCPR, such as Articles 2 (1), 3, 14, 24, 25, and 26 ICCPR. This analysis reveals an interesting pattern. Most of the cases in which the Committee found a violation of equality involve discrimination based on suspect criteria of distinction, such as sex, citizenship, race, sexual orientation or political opinion. In addition, the HRC also finds violations of equality in cases of arbitrary administrative or legislative practices. Section 5 concludes and provides an overall assessment of the HRC's equality jurisprudence.

\section{The conundrum of equality}

While we all have an intuitive understanding of equality, at closer sight, the conceptualization of equality poses a conundrum. ${ }^{5}$ Equality is often understood in a formal way, which is associated

\footnotetext{
${ }^{2}$ On equality and non-discrimination in international law see generally E. W. Vierdag, The Concept of Discrimination in International Law (1973); W. MacKean, Equality and Discrimination under International Law (1983); M. J. Bossuyt, L'interdiction de la discrimination dans le droit international des droits de l'homme (1976); A. F. Bayefsky, 'The Principle of Equality or Non-Discrimination in International Law', (1990) 11 Human Rights Law Journal 1; M. C. R. Craven, 'Non-Discrimination and Equality', in M. C. R. Craven (ed.), The International Covenant on Economic, Social and Cultural Rights: A Perspective on Its Development (1995), 153; S. Fredman, 'Combating Racism with Human Rights: The Right to Equality', in S. Fredman (ed.), Discrimination and Human Rights: The Case of Racism (2001), 9; N. Lerner, Group Rights and Discrimination in International Law (2003); W. Vandenhole, Non-Discrimination and Equality in the View of the UN Human Rights Treaty Bodies (2005); K. Henrard, 'Equality of Individuals', in R. Wolfrum (ed.), Max Planck Encyclopedia of Public International Law (2008); J. Clifford, 'Equality', in D. Shelton (ed.), The Oxford Handbook of International Human Rights Law (2013), 420; D. Moeckli, 'Equality and Non-Discrimination', in D. Moeckli, S. Shah and S. Sivakumaran (eds.), International Human Rights Law (2014), 157.

${ }^{3}$ For a detailed account of the UN Human Rights Committee see Y. Tyagi, The UN Human Rights Committee: Practice and Procedure (2011). See also V. Shikhelman, 'Implementing Decisions of International Human Rights Institutions - Evidence from the United Nations Human Rights Committee', (2019) 30 European Journal of International Law 753.

${ }^{4}$ There are quite a few accounts on the interpretation of Art. 26 ICCPR, see B. G. Ramcharan, 'Equality and Nondiscrimination', in L. Henkin (ed.), The International Bill of Rights: The Covenant on Civil and Political Rights (1981), 246; C. Tomuschat, 'Equality and Non-Discrimination under the International Covenant on Civil and Political Rights', in I. von Münch (ed.), Staatsrecht - Völkerrecht - Europarecht: Festschrift für Hans-Jürgen Schlochauer (1981), 691; T. Opsahl, 'Equality in Human Rights Law with Particular Reference to Article 26 of the International Covenant on Civil and Political Rights', in M. Nowak (ed.), Fortschritt im Bewusstsein der Grund- und Menschenrechte: Festschrift für Felix Ermacora (1988), 51; T. Choudhury, 'Interpreting the right to equality under Article 26 of the International Covenant on Civil and Political Rights', (2003) 8 European Human Rights Law Review 24; C. Edelenbos, 'The Human Rights Committee's Jurisprudence Under Art. 26 of the ICCPR: The Hidden Revolution', in G. Alfredsson et al. (eds.), International Human Rights Monitoring Mechanisms: Essays in Honour of Jakob Th. Möller (2009), 77; M. Nowak, U.N. Covenant on Civil and Political Rights: CCPR Commentary (2015), Art. 26, at 597-634.

${ }^{5}$ This was pointed out, in particular, by Westen, supra note 1 .
} 
with the Aristotelian idea that like cases should be treated alike and unlike cases should be treated differently. However, two individuals will never be equal in all respects. Therefore, we have to determine according to which factors everyone should be treated equally. Yet, the concept of equality does not help us in determining these factors so that we have to return to external standards of justice. ${ }^{6}$ One instructive example to exemplify this conundrum is the discussion on social equality. What does social equality mean? Does it imply that everybody should have the same means or, rather, the same opportunities? Equality itself does not give an answer in this respect. In legal literature and judicial practice, there are basically two diverging approaches to deal with this challenge. Either equality is interpreted as a non-discrimination guarantee protecting vulnerable groups or as a consistency requirement. In the following, I will briefly introduce these two approaches in broad strokes.

\subsection{Equality as a guarantee protecting vulnerable groups}

One approach interprets equality as a non-discrimination guarantee, which primarily focuses on the protection of vulnerable groups. Under this approach, violations of the equality guarantee would be restricted to distinctions based on a suspect criterion. A prominent operationalization of this approach is the tiered scrutiny doctrine of the US Supreme Court, according to which a violation of the equal protection clause of the 14th Amendment of the US Constitution is significantly more likely if the distinction was based on one of several suspect criteria that have been identified by the court. ${ }^{7}$

One crucial aspect of this approach is the identification of what constitutes a suspect criterion. Many non-discrimination guarantees in international human rights treaties and national constitutions contain an explicit list of characteristics considered as problematic criteria of distinction. However, these lists are usually open-ended. Courts often extend these lists in order to reflect changing social circumstances. A prominent example for a criterion of distinction that, today, is commonly regarded as suspect without being contained in the explicit lists of most nondiscrimination guarantees is sexual orientation. For example, the European Court of Human Rights (ECtHR) has repeatedly argued that sexual orientation is 'undoubtedly covered by Article 14 of the Convention', even though it is not explicitly included in the norm. ${ }^{8}$ Similarly, the Inter-American Court of Human Rights (IACtHR) has consistently qualified discrimination based on sexual orientation as violations of the equality guarantee of Article 24 of the American Convention on Human Rights (ACHR). ${ }^{9}$

There is an elaborate debate on what makes a criterion 'suspect'. ${ }^{10}$ In his seminal monograph, Tarunabh Khaitan has identified two conditions under which a criterion can be considered as

\footnotetext{
${ }^{6}$ Ibid., at 557.

${ }^{7}$ On the equal protection clause in the U.S. Constitution see, e.g., G. Gunther, 'In Search of Evolving Doctrine on a Changing Court: A Model for a Newer Equal Protection', (1972) 86 Harvard Law Review 1; J. Balkin and R. B. Siegel, 'The American Civil Rights Tradition: Anticlassification or Antisubordination', (2003) 2 Issues in Legal Scholarship 1; A. Winkler, 'Fatal in Theory and Strict in Fact: An Empirical Analysis of Strict Scrutiny in the Federal Courts', (2006) 59 Vanderbilt Law Review 793; R. H. Fallon, 'Strict Judicial Scrutiny', (2007) 54 UCLA Law Review 1267; K. Yoshino, 'The New Equal Protection', (2011) 124 Harvard Law Review 747.

${ }^{8}$ Salgueiro da Silva Mouta v. Portugal, Judgment of 21 December 1999, [1999] ECHR 1999-IX, 309, para. 28. See also L. and V. v. Austria, Judgment of 9 January 2003, [2003] ECHR 2003-I, 29, para. 45; Vallianatos v. Greece, Judgment of 7 November 2013, [2013] ECHR 2013-VI, 125, para. 77.

${ }^{9}$ Identidad de género, y no discriminación a parejas del mismo sexo, Advisory Opinion of 24 November 2017, [2017], IACHR OC-24/17, para. 66; Atala Riffo and Daughters v. Chile, Judgment of 24 February 2012, [2012] IACHR (Ser. C), paras. 85-91; Duque v. Colombia, Judgment of 26 February 2016, [2016], IACHR (Ser. C), para. 104; Flor Freire v. Ecuador, Decision of 4 November 2013, [2013], IACHR (Ser. C), para. 100; Ramírez Escobar and others v. Guatemala, Judgment of 9 March 2018 , [2013], IACHR (Ser. C), para. 302. See also N. Carrillo-Santarelli, 'Gender Identity, and Equality and Non-discrimination of Same Sex Couples', (2018) 112 American Journal of International Law 479.

${ }^{10}$ See, e.g., J. H. Ely, Democracy and Distrust (1980), 135-79; Sunstein, supra note 1; Khaitan, supra note 1, at 49-62.
} 
suspect: First, it makes a distinction between different groups, and members of one group are more likely to suffer a substantial disadvantage; and second, the classifying characteristic is either immutable or reflects a fundamental choice. ${ }^{11}$ The first condition relates to the vulnerability of the protected group. This vulnerability can be determined based on a history of past discrimination and a lower social status in the present. ${ }^{12}$ Race is a suspect criterion of distinction because of the long history of racial discrimination that we have seen in many regions of the world. ${ }^{13}$ By contrast, eye colour is usually not considered a suspect criterion because it has, as yet, not been used to designate a lower social status to vulnerable groups. Lower social status leads to an underrepresentation of the interests of the vulnerable group in the political process. ${ }^{14}$ Therefore, it often translates into disadvantageous legislation or administrative practices reinforcing the inferior social status of the concerned group.

The second condition is necessary in order to exclude mere decisional minorities from the protection of non-discrimination guarantees. Democratic decision-making always knows winners and losers, and the minority in a democratic decision-making process is not per se entitled to protection under non-discrimination guarantees. ${ }^{15}$ At the same time, merely focusing the second condition on physical immutability would be too narrow. ${ }^{16}$ Many physical traits, like sex, can be changed - even though sometimes only at great cost. Social status may be mutable in theory but only with great difficulty in practice. Finally, there are some classifying criteria, such as religion, which can be changed. However, an involuntary change is normatively undesirable because the characteristic is central to the concerned person's identity. ${ }^{17}$ Therefore, the second condition is fulfilled if the characteristic in question is either strictly or effectively immutable or represents a fundamental choice.

Certainly, the identification of suspect criteria is not automatic. The vulnerability of a social group is not a categorical characteristic but rather a matter of degree. Some groups are more vulnerable than others so that, in certain cases, one may reasonably disagree whether a specific criterion should be classified as suspect or not. Furthermore, once we have identified a criterion as suspect, this does not mean that all distinctions based on such a criterion are automatically a violation of the non-discrimination guarantee. On the one hand, even if a measure disadvantages a vulnerable group, it may, under certain circumstances, be justified if it is necessary to pursue a common goal. For example, Article 26 ICCPR prohibits discrimination based on language in order to protect linguistic minorities. Nevertheless, it seems uncontroversial that states can designate an official language and limit official communication to this language for reasons of administrative practicality.

On the other hand, there is a controversial discussion on whether non-discrimination guarantees should be applied symmetrically. ${ }^{18}$ If one agrees with the group-based justification, according to which suspect criteria are supposed to identify vulnerable groups, an asymmetric application seems preferable. A measure disadvantaging black citizens in a majority white society is highly problematic according to this concept because of the history of past discrimination against blacks. However, a measure that disadvantages whites is not necessarily problematic because whites are not a vulnerable group and usually face no systematic discrimination.

\footnotetext{
${ }^{11}$ Khaitan, ibid., at 50 .

${ }^{12}$ Hellman, supra note 1, at 14-15; see also Sunstein, supra note 1, at 2433.

${ }^{13}$ Fiss, supra note 1.

${ }^{14}$ See Ely, supra note 10, at 157-70.

${ }^{15}$ See J. Waldron, 'The Core of the Case Against Judicial Review', (2006) 115 Yale Law Journal 1346, at 1398.

${ }^{16}$ Khaitan, supra note 1 , at $58-60$.

${ }^{17}$ Ibid., at 59 .

${ }^{18}$ See Fiss, supra note 1; M. Abram, 'Affirmative Action: Fair Shakers and Social Engineers', (1986) 99 Harvard Law Review 1312; N. Gotanda, 'A Critique of "Our Constitution is Color-Blind”, (1991) Stanford Law Review 1; K. Yoshino, 'Assimilationist Bias in Equal Protection: The Visibility Presumption and the Case of “Don't Ask, Don't Tell”, (1998) 108 Yale Law Journal 485; Khaitan, supra note 1, at 61-2.
} 
Nevertheless, the case law of the US Supreme Court is a prominent illustration that equalityas-discrimination approaches do not necessarily have to be asymmetrical. ${ }^{19}$

\subsection{Equality as consistency requirement}

The opposite approach interprets equality as a consistency requirement. ${ }^{20}$ This approach considers equality as an individual guarantee, which targets inconsistencies in legislation and administrative action, as opposed to a guarantee protecting vulnerable groups. Because this interpretation is not group-focused, an equality guarantee can be violated even if a measure has not made a distinction based on a suspect criterion. Rather, the violation of the equality norm only requires that like cases have not been treated alike and that there is no justification for the distinction. Consequently, any distinction, no matter how unimportant, can trigger an equality analysis. Therefore, the main focus of this interpretation of equality lies in the justification analysis where courts have to determine whether a specific distinction was justified. On a constitutional level, this model has primarily been adopted by the German Federal Constitutional Court. ${ }^{21}$

\subsection{Comparison of the two approaches}

These two models are archetypes at the opposite ends of a scale, whose elements are not mutually exclusive. Instead, it is possible that courts adopt models with elements of both approaches that would be situated somewhere in the intermediary space between the two. Note that the judicial approach is not necessarily predetermined by the wording of the equality norm contained in the specific human rights catalogue. While we usually find two types of equality norms, that is, general equality norms that protect the formal equality before the law, and non-discrimination guarantees, which prohibit the discrimination of certain, specific grounds, they usually allow courts considerable flexibility. An excellent example is Article 26 ICCPR. While the norm contains a non-discrimination guarantee, prohibiting discrimination based on specific grounds, the list of prohibited grounds is open-ended because it also contains a prohibition to discriminate based on 'other status'. Furthermore, the norm also contains a protection of formal equality in that it states that '[a]ll persons are equal before the law'.

In normative terms, neither of the two models has a clear edge. Instead, both approaches have their own particular downsides. The consistency approach runs into the problem that we have outlined above: It lacks a clear standard of what should be considered a violation of equality. By comprising all kinds of distinctions, no matter how unimportant, it shifts the burden of the analysis to the justification stage without being able to specify under which conditions an unequal treatment can be justified. By contrast, the non-discrimination approach addresses this problem by focusing on specific suspect criteria of distinction. Not all inequalities are relevant, only those on explicitly mentioned dimensions. Nevertheless, this model also has certain shortcomings: First, the identification of suspect criteria and their symmetrical application may be controversial. Second, the approach might be under-inclusive by not addressing arbitrary state action if a public authority makes a distinction not covered by the pre-identified criteria. ${ }^{22}$ Finally, it somehow has to address indirect discrimination: Under which conditions do indirect discrimination of measures which are not explicitly based on a suspect criterion violate equality if they have a discriminatory effect?

\footnotetext{
${ }^{19}$ See, e.g., Regents of the University of California v. Bakke, [1978] 438 U.S. 265, at 355-62. For a scathing critique of this approach see I. F. Haney López, 'Equal Protection as Intentional Blindness', in R. Oakes (ed.), Controversies in Equal Protection Cases in America (2015), 67.

${ }^{20}$ On this approach see Fredman, supra note 2, at 16-18; Clifford, supra note 2, at 427-8; Moeckli, supra note 2, at 158-9.

${ }^{21}$ See N. Petersen, 'Gleichheitssatz und Einzelfallgerechtigkeit', (2018) 57 Der Staat 327.

${ }^{22}$ See E. Chemerinsky, 'The Rational Basis Test is Constitutional (and Desirable)', (2016) 14 Georgetown Journal of Law \& Public Policy 401; J. Greene, 'Rights as Trumps', (2018) 132 Harvard Law Review 28, at 43-7.
} 


\section{Emptiness of the doctrinal formulae of the Human Rights Committee}

The ICCPR contains several equality norms. The most important norm is Article 26 ICCPR, which protects the equality before the law and prohibits discrimination based on certain, specific grounds. Furthermore, the Convention also contains an accessory prohibition of discrimination in Article 2(1) ICCPR, guarantees of equality between men and women in Article 3 ICCPR, before courts and tribunals in Article 14 ICCPR, as well as specific prohibitions of discrimination regarding children in Article 24 ICCPR, and in the context of elections and public service in Article 25 ICCPR. In the individual communications of the HRC, the most important norm is Article 26 ICCPR. The other equality norms only play a minor role.

Consequently, I will primarily focus on Article 26 ICCPR in this section and reconstruct the doctrine that the HRC has developed in the context of its equality case law. I will concentrate on three aspects. First, the HRC has primarily operationalized equality by developing a formula according to which distinctions violate Article 26 ICCPR if they are not based on 'objective and reasonable' criteria. I will analyse how the HRC has conceptualized this requirement (Section 3.1). Second, I will have a closer look at the relationship between the general guarantee of equality before the law and the specific criteria of discrimination mentioned in the norm: Do the latter have a special status and require additional justification? (Section 3.2). Third, I will examine the concept of indirect discrimination and discuss how the HRC deals with cases, in which a measure is not based on an explicit suspect distinction, but has a discriminatory effect (Section 3.3). The fourth part draws some preliminary conclusions (Section 3.4).

\subsection{Distinctions based on reasonable and objective criteria}

Very early in its jurisprudence, the HRC developed a two-step test to operationalize the equality and non-discrimination guarantees, in particular, Article 26 ICCPR. While we can see elements of the test in earlier decisions, it was first pronounced in Danning v. the Netherlands. ${ }^{23}$ The case was about accident insurance benefits, which were more favourable for married individuals than for unmarried ones. The author of the individual communication claimed that he should get the higher benefits because he was living with his partner in a common-law marriage. The Committee argued that:

The right to equality before the law and to equal protection of the law without any discrimination does not make all differences of treatment discriminatory. A differentiation based on reasonable and objective criteria does not amount to prohibited discrimination within the meaning of article $26 .{ }^{24}$

In the first step, the Committee determines whether there is a difference of treatment, and in the second, whether this differentiation is based on 'reasonable and objective criteria'. ${ }^{25}$ This formula is similar to the one adopted by the ECtHR in the Belgian linguistics case, where the Court argued that 'the principle of equality of treatment is violated if the distinction has no objective and reasonable justification ${ }^{26}$ However, the ECtHR added that such a justification required the pursuit of

\footnotetext{
${ }^{23}$ L. G. Danning v. The Netherlands, 9 April 1987, UN Doc. CCPR/C/OP/2, at 205.

${ }^{24}$ Ibid., para. 13 (emphasis added).

${ }^{25} \mathrm{Ibid}$.

${ }^{26}$ Case Relating to Certain Aspects of the Laws on the Use of Languages in Education in Belgium, Decision of 23 July 1968 , [1968] ECHR (Ser. A), at 6 (emphasis added). On the equality jurisprudence of the ECHR see generally O. M. Arnardóttir, Equality and Non-Discrimination under the European Convention of Human Rights (2003); S. Besson, 'Gender Discrimination under EU and ECHR Law: Never Shall the Twain Meet?', (2008) 8 Human Rights Law Review 647; R. O'Connell, 'Cindarella comes to the Ball: Art. 14 and the right to non-discrimination in the ECHR', (2009) 29 Legal Study 211; T. Altwicker, Menschenrechtlicher Gleichheitsschutz (2011); J. Gerards, 'The Discrimination Grounds of Article 14 of the European Convention on Human Rights', (2013) 13 Human Rights Law Review 99; O. M. Arnardóttir, 'The Differences that Make a Difference: Recent Developments on the Discrimination Grounds and the Margin of Appreciation under Article 14 of the European Convention of Human Rights', (2014) 14 Human Rights Law Review 647.
} 
a legitimate aim and a 'reasonable relationship of proportionality'. ${ }^{27}$ Similarly, the IACtHR equally requires that a different treatment has to have a legitimate purpose and that it is not 'disproportionate to the purpose sought'. ${ }^{28}$

By contrast, the HRC has never consistently specified the meaning of the terms 'reasonable and objective criteria'. Even in its General Comment No. 18, the Committee merely repeats that the criteria for a differentiation have to be 'reasonable and objective' and that the distinction has to achieve a legitimate purpose in order to be justified. ${ }^{29}$ However, it does not specify these requirements any further.

In some individual communications, the Committee uses elements of proportionality. In Jacobs, for example, the Committee held that a gender quota for judges did not violate Article 26 because it did not 'amount to a disproportionate restriction of candidates' right of access' ${ }^{30}$ In other decisions, one gets the impression that the second step of the test seeks to weed out intentional discrimination. This is particularly manifest in Järvinen, where the HRC found the challenged measure to be justified because ' $[\mathrm{t}]$ he legislation . . . had no discriminatory purpose. ${ }^{31}$

However, these elements cannot be observed on a consistent basis. They appear in singular decisions but are not picked up and developed in subsequent individual communications. The problem of the reasonable-and-objective-criteria test is that its terms are so vague that they give little guidance to decide actual cases. The Committee's flip-flop in its jurisprudence on different service times for military and civil service illustrates these difficulties. The already mentioned Järvinen case dealt with this question in the Finnish context. ${ }^{32}$ While military service lasted eight months, conscientious objectors, who had to do alternative civil service, had to serve for 16 months. The Committee accepted the Finnish allegations that the longer service time served as a proof of the genuineness of the ethical or religious convictions that were the basis for the conscientious objection. It argued that the distinction was based on 'practical considerations' and therefore on 'reasonable and objective criteria'. ${ }^{33}$

By contrast, when the same question came up in a series of cases against France, the Committee took the opposite position. ${ }^{34}$ In the French cases, civilian service for conscientious objectors lasted two years, while military service did not exceed one year. France used a similar argument as the one on which Finland relied in Järvinen: asking conscientious objectors to serve for a longer time period was a means to test the sincerity of their motives. However, in this case, the Committee rejected the argument: 'In the Committee's view, such argument does not satisfy the requirement that the difference in treatment involved in the present case was based on reasonable and objective criteria. ${ }^{35}$ The Committee did not mention its decision in Järvinen and did not even try to justify this U-turn. While an extreme example, the cases surrounding the length of service for military and alternative service illustrate the malleability of the 'reasonable and objective criteria' formula. The same formula can be used to justify two diametrically opposite results.

\footnotetext{
${ }^{27}$ Certain Aspects of the Laws on the Use of Languages in Education in Belgium, supra note 26.

${ }^{28}$ Norín Catrimán et al. (Leaders, Members and Activist of the Mapuche Indigenous People) v. Chile, Judgment of 29 May 2014, [2014] IACHR (Ser. C), para. 200.

${ }^{29}$ Human Rights Committee, General Comment No. 18: Non-discrimination, HRI/GEN/1/Rev.1 (1989) at 26, para. 13.

${ }^{30}$ Jacobs v. Belgium, UN Doc. CCPR/C/81/D/943/2000, para. 9.5 (emphasis added).

${ }^{31}$ Järvinen v. Finland, UN Doc. CCPR/C/39/D/295/1988, para. 6.4 (emphasis added).

${ }^{32}$ Ibid.

${ }^{33}$ Ibid., para. 6.4

${ }^{34}$ Foin v. France, 3 November 1999, UN Doc. CCPR/C/67/D/666/1995; Maille v. France, 10 July 2000, UN Doc. CCPR/C/ 69/D/689/1996; Venier and Nicolas v. France, 10 July 2000, UN Doc. CCPR/C/69/D/690/1996.

${ }^{35}$ Foin v. France, supra note 34, para. 10.3 (emphasis added).
} 


\subsection{Special status of the criteria of discrimination mentioned in Article 26 ICCPR}

If the justification test is as malleable as the one developed by the HRC in the context of Article 26 ICCPR, the definition of the scope of the provision becomes all the more important. The scope of Article 26 ICCPR is not limited to discrimination based on the specifically mentioned 'suspect' criteria. Rather, there are two elements allowing the HRC to broaden the scope of the norm. On the one hand, the norm prohibits discrimination based on 'other status'; on the other hand, it also generally protects 'equality before the law'. Therefore, one may wonder what the importance of the specifically mentioned criteria in Article 26 ICCPR is: Do measures that make a distinction based on one of the explicitly mentioned criteria have to fulfil additional requirements in order to be justified?

The ECtHR has specified its approach regarding Article 14 ECHR in its later jurisprudence by giving a special importance to the criteria of distinction mentioned in the norm. According to the Court, 'only differences in treatment based on an identifiable characteristic, or "status", are capable of amounting to discrimination within the meaning of Article $14{ }^{36}$ By contrast, for a long time, the HRC did not directly address this issue. Instead, the Committee referred to its general formula that differentiations are justified when based 'on reasonable and objective criteria', regardless of whether one of the explicitly mentioned suspect criteria was involved or not. One example is the already mentioned decision in Järvinen. ${ }^{37}$ The distinction between military and alternative service is not specifically mentioned in Article 26 ICCPR. However, the HRC did not discuss the existence and requirement of a distinction based on a suspect criterion. Instead, it went straight to the justification analysis: 'Article 26 of the Covenant, while prohibiting discrimination and guaranteeing equal protection of the law to everyone, does not prohibit all differences of treatment. Any differentiation ... must[,] however, be based on reasonable and objective criteria. ${ }^{38}$

For the first time, the Committee explicitly addressed the problem in Müller and Engelhard. ${ }^{39}$ The authors of the individual communication challenged a Namibian regulation according to which the husband could only adopt the surname of his wife after a costly and burdensome procedure, while the wife was usually assumed to adopt her husband's name. The Committee found that the norm amounted to discrimination based on sex. It further argued that a differential 'treatment based on one of the specific grounds enumerated in article 26, clause 2 of the Covenant ... places a heavy burden on the State party to explain the reason for the differentiation' ${ }^{40}$ In the concrete case, it held that the norm was not justifiable.

According to this interpretation, a differentiation based on a suspect criterion imposes a burden of justification on the concerned state. However, this aspect cannot be found in the later jurisprudence. Instead, the Committee came up with a different formula in Pohl v. Austria in $2004 .{ }^{41}$ The individual communication concerned an obligation to pay a financial contribution for the construction of sewers. The amount of these contributions was based on the square measure of a plot benefiting from these sewers. The authors argued that the calculation of the contribution did not take into account the special circumstances of rural areas and was thus arbitrary. Unlike in previous decisions, the Committee noted that Article 26 ICCPR prohibited discrimination based on the specific grounds mentioned in the article. ${ }^{42}$ It then argued that the particular distinction in this case was 'neither discriminatory by reference to any of the grounds mentioned in article 26 of the Covenant, nor arbitrary'. ${ }^{43}$

\footnotetext{
${ }^{36}$ Carson and Others v. the United Kingdom [GC], Judgment of 16 March 2010, [2010] ECHR 2010-II, 407, para. 61. See also Clift v. UK, Judgment of 13 July 2010, [2010] App. No. 7205/07, para. 55.

${ }^{37}$ Järvinen v. Finland, supra note 31.

${ }^{38}$ Ibid., para. 6.3 .

${ }^{39}$ Müller and Engelhard v. Namibia, 26 March 2002, UN Doc. CCPR/C/74/D/919/2000.

${ }^{40}$ Ibid., para. 6.7 .

${ }^{41}$ Pohl et al. v. Austria, 9 July 2004, UN Doc. CCPR/C/81/D/1160/2003.

${ }^{42}$ Ibid., para. 9.3.

${ }^{43}$ Ibid.
} 
Therefore, the decision suggests that distinctions which are not either direct or indirect discrimination based on one of the explicitly mentioned criteria only violate Article 26 ICCPR if they are arbitrary. This approach was mirrored in the case of Jongenburger-Veerman, which dealt with the distinction between members of the Assistant Corps and other public servants in the context of social benefits. ${ }^{44}$ Here, the Committee again referred to the explicitly mentioned criteria and added that the reasons motivating the legislature to make the challenged distinction did, furthermore, not 'disclose a lack of reasonableness and objectivity'. ${ }^{45}$ In O'Neill and Quinn, finally, the Committee again referred to arbitrariness when discussing the general guarantee of equality before the law referring to a distinction not based on a specifically mentioned criterion. ${ }^{46}$

However, the Committee did not continue this line of jurisprudence. Instead, in later cases, it falls back to the simple analysis of whether a distinction has been based on reasonable and objective grounds, regardless of whether any of the mentioned criteria have been concerned or not. ${ }^{47}$ Consequently, the HRC's doctrine to operationalize equality does, overall, not suggest a difference between distinctions based on the criteria explicitly mentioned in Article 26 ICCPR and other distinctions, which are not specifically based on suspect criteria.

\subsection{Indirect discrimination}

The final doctrinal question addressed in this section concerns indirect discrimination: To what extent should indirect discrimination lead to a violation of Article 26 ICCPR ${ }^{48}$ Initially, the Committee lacked sensitivity with regard to this issue. In Ballantyne, it had to decide whether French language requirements for advertisements in Quebec were to be considered discriminatory. ${ }^{49}$ The Committee dismissed the challenge and argued that there was no discriminatory treatment because a Francophone trying to advertise in English would be concerned the same way. ${ }^{50}$ That the regulation might lead to an indirect discrimination because Anglophones are more likely to have the intention to advertise in English than Francophones was not even discussed. ${ }^{51}$

For the first time, the Committee acknowledged the concept of indirect discrimination in Althammer. ${ }^{52}$ The individual communication concerned Austrian legislation which replaced a household allowance for public servants with an increased children's allowance for children under the age of 27. The authors complained that this change of legislation amounted to age discrimination because older public servants were more likely to have older children. The Committee agreed that norms do not necessarily have to be discriminatory on their face in order to violate Article 26 ICCPR: 'The Committee recalls that a violation of article 26 can also result from the discriminatory effect of a rule or measure that is neutral at face value or without intent to discriminate. ${ }^{53}$

In the concrete case, however, it found that the Austrian law was not discriminatory because it was based on objective and reasonable grounds. ${ }^{54}$ Whoever thought that Althammer would be a turning point of the Committee showing greater sensitivity towards indirect discrimination was

\footnotetext{
${ }^{44}$ Jongenburger-Veerman v. the Netherlands, 1 November 2005, UN Doc. CCPR/C/85/D/1238/2004.

${ }^{45}$ Ibid., para. 7.2.

${ }^{46}$ O'Neill and Quinn v. Ireland, 24 July 2006, UN Doc. CCPR/C/87/D/1314/2004, para. 8.4.

${ }^{47}$ See Conçalves et al. v. Portugal, 18 March 2010, UN Doc. CCPR/C/98/D/1565/2007, para. 7.5; Alekperov v. Russia, 21 October 2013, UN Doc. CCPR/C/109/D/1764/2008, para. 9.10; Whelan v. Ireland, 17 March 2017, UN Doc. CCPR/C/119/D/ 2425/2014, para. 7.12 .

${ }^{48}$ On the HRC's jurisprudence on indirect discrimination see also Moeckli, supra note 2, at 165.

${ }^{49}$ Ballantyne et al. v. Canada, 31 March 1993, UN Doc. CCPR/C/47/D/359/1989.

${ }^{50}$ Ibid., para. 11.5 .

${ }^{51}$ See also the critique of Nowak, supra note 4, Art. 26, para. 34 in this respect. As in Ballantyne, the Committee did not discuss a possible indirect discrimination in Oulajin and Kaiss v. the Netherlands, 23 October 1992, UN Doc. CCPR/C/46/D/ 406/1990, even though the case would have merited such a discussion.

${ }^{52}$ Althammer et al. v. Austria, 8 August 2003, UN Doc. CCPR/C/78/D/998/2001.

${ }^{53}$ Ibid., para. 10.2 .

${ }^{54}$ Ibid.
} 
quickly disappointed. Instead, it seems that the formula only paid lip-service to the concept without actually engaging with its substance and implications. This is demonstrated by the decision in Prince, which deals with the question of whether South Africa was obliged to grant an exception from the general prohibition of cannabis consumption for religious use. ${ }^{55}$ In its decision, the Committee simply argued that the prohibition to consume cannabis 'affects all individuals equally' and was thus not discriminatory. ${ }^{56}$ Again, it did not even consider the question of whether the prohibition might be an indirect discrimination based on religion. While coming to the same result, the prior decision of the South African Constitutional Court on the same matter had been much more nuanced in its reasoning. ${ }^{57}$

\subsection{Conclusions}

This section has shown that the doctrinal approach of the HRC to Article 26 ICCPR is inconsistent. The only constant in the Committee's jurisprudence is the formula that distinctions have to based on 'objective and reasonable grounds' to be justified. However, this formula is far too malleable to have a sufficient guiding function for the decision-making of the HRC. ${ }^{58}$ This is demonstrated most clearly by the cases regarding conscientious objectors in Finland and France. Even though the facts of both situations are broadly comparable, the Committee comes to opposite results employing the objective-and-reasonable-grounds formula.

The jurisprudence regarding the role of the explicitly mentioned suspect criteria in Article 26 ICCPR shows some promising starting points. The Committee has argued that distinctions based on suspect grounds impose a heavy burden of justification on the respondent state. Furthermore, it has reasoned that distinctions not based on one of the explicitly mentioned suspect criteria violate Article 26 ICCPR only if they are arbitrary. While these are both reasonable approaches, the Committee has failed to develop a consistent doctrine. Instead, formulae which have once been introduced are not picked up in later cases. Finally, the Committee failed to address the concept of indirect discrimination: While it partly paid lip-service to the concept, it failed to apply it consistently or to specify its implications.

\section{Analysis of the case law}

Despite this vagueness and inconsistency in the doctrinal formulae, we can observe a certain pattern not reflected in the doctrine once we examine the case law in more detail. The following analysis is based on an examination of all individual communications until the end of 2019, in which the HRC ruled on the substance of an equality norm of the Covenant. It comprises 83 individual communications ${ }^{59}$ and coded these cases regarding different dimensions, such as the concerned equality norm, whether or not the individual communications were successful, the kind of distinction that was challenged (e.g., sex, race, nationality, religion, etc.), and the subject matter of the challenge (e.g., family, taxes, social welfare, military/police violence).

If we only look at the cases in which the HRC found a violation, we can observe that the challenged distinction was, in the vast majority of cases, based on a suspect classification (Section 4.1). However, there are some cases, in which the Human Rights Committee found a violation even though the distinction in question was not based on a suspect classification (Section 4.2). Arguably, in most of these cases, the Committee targeted arbitrary administrative action. After having analysed the cases in which the HRC found a violation, the last subsection turns to the cases in which it did not find a violation and analyses whether the pattern holds in this situation as well (Section 4.3).

\footnotetext{
${ }^{55}$ Prince v. South Africa, 31 October 2007, UN Doc. CCPR/C/91/D/1474/2006.

${ }^{56}$ Ibid., para. 7.5 .

${ }^{57}$ Prince v. President of the Law Society of the Cape of Good Hope (CCT 36/00) [2002] SA 794.

${ }^{58}$ Similarly, Bayefski, supra note 2, at 14 (calling the approach of the HRC 'uneven and confused').

${ }^{59}$ The analysis does not comprise repetitive decisions, that is, decisions which concern the same issue in the same country that has already been addressed by the HRC in a previous decision.
} 


\subsection{Discrimination based on suspect classifications}

Most cases in which the HRC found a violation of Article 26 ICCPR or the equivalent equality norms concerned discrimination based on suspect classifications. The majority of these cases deal with sex discrimination (Section 4.1.1). There is also a significant number of cases dealing with discrimination based on citizenship (Section 4.1.2), sexual orientation or gender identity (Section 4.1.3), and political opinion (Section 4.1.4). There is a single case dealing with race discrimination (Section 4.1.5), and there are a few individual communications concerning other suspect classifications (Section 4.1.6).

\subsubsection{Sex discrimination}

Sex discrimination against women has a long history, and even today, women face disadvantages of different degrees in most societies. Therefore, sex is widely recognized as a suspect criterion. ${ }^{60} \mathrm{It}$ is explicitly mentioned in Article 26 ICCPR. In addition, Article 3 of the Convention highlights the obligation of the state parties to ensure the equal right of men and women and thus underlines the suspect nature of the criterion. ${ }^{61}$ Furthermore, several international treaties and documents protecting women's rights - the Convention on the Elimination of All Forms of Discrimination against Women ${ }^{62}$ being the most notable - stress the importance that the international community attributes to the issue. ${ }^{63}$

Therefore, it is not surprising that a significant number of cases in which the Human Rights Committee found a violation of the equality norms under the ICCPR were sex discrimination cases. ${ }^{64}$ The earlier cases often dealt with stereotypical classifications in social benefits legislation, which assumed that men were the breadwinners of the family, while women were financially dependent on their husbands. ${ }^{65}$ In S.W.M. Broeks, the Committee reviewed Dutch legislation, according to which women had to show that they were breadwinners of the family in order to receive unemployment benefits, while no such obligation was imposed on men. ${ }^{66}$ The HRC argued that this distinction between men and women was 'not reasonable' and found a corresponding discrimination. ${ }^{67}$ In Pauger, the Committee found that Austrian social benefits legislation, which gave female widows an unconditional claim to a widow's allowance, while men only received such an allowance if they were not gainfully employed, was not reasonable. ${ }^{68}$

More recent cases often found sex discrimination because of gender-based violence. ${ }^{69}$ In Purna Maya, the author of the individual communication had been gang-raped by members of the

\footnotetext{
${ }^{60}$ See Bayefski, supra note 2, at 20-3.

${ }^{61}$ Henrard, supra note 2, para. 7.

${ }^{62}$ UNTS 1249, at 13.

${ }^{63}$ See, generally, C. Chinkin, 'Women, Rights of, International Protection', in R. Wolfrum (ed.), Max Planck Encyclopedia of Public International Law (2010).

${ }^{64}$ Aumeeruddy-Cziffra vs. Mauritius, 9 April 1981, UN Doc. CCPR/C/OP/1 at 67; S.W.M. Broeks v. the Netherlands, 9 April 1987, UN Doc. CCPR/C/29/D/172/1984; Zwaan-de Vries v. the Netherlands, 9 April 1987, UN Doc. CCPR/C/29/D/182/1984; Ato de Avellanal v. Peru, 28 October 1988, UN Doc. CCPR/C/34/D/202/1986; Pauger v. Austria (1), 26 March 1992, UN Doc. CCPR/C/44/D/415/1990; Pauger v. Austria (2), 25 March 1999, UN Doc. CCPR/C/65/D/716/1996; Müller and Engelhard v. Namibia, supra note 39; Mellet v. Ireland, 31 March 2016, UN Doc. CCPR/C/116/D/2324/2013; Purna Maya v. Nepal, 17 March 2017, UN Doc. CCPR/C/119/D/2245/2013; X v. Sri Lanka, 27 July 2017, UN Doc. CCPR/C/120/D/2256/2013; Cacho Ribeiro v. Mexico, 17 July 2018, UN Doc. CCPR/C/123/D/2767/2016; Türkan v. Turkey, 17 July 2018, UN Doc. CCPR/C/123/2274/2013; Nyaya v. Nepal, 18 March 2019, UN Doc. CCPR/C/125/D/2556/2015.

${ }^{65}$ S.W.M. Broeks v. the Netherlands, supra note 64; Zwaan-de Vries v. the Netherlands, supra note 64; Pauger v. Austria (1), supra note 64; Pauger v. Austria (2), supra note 64. Gender-stereotyping was also a main reason for violations of Art. 26 ICCPR in two cases concerning Irish abortion practices, see Mellet $v$. Ireland, supra note 64; Whelan v. Ireland, supra note 47.

${ }^{66}$ S. W.M. Broeks v. the Netherlands, supra note 64.

${ }^{67}$ Ibid., para. 14.

${ }^{68}$ Pauger v. Austria (1), supra note 64, para. 7.4.

${ }^{69}$ Purna Maya v. Nepal, supra note 64; Xv. Sri Lanka, supra note 64; Cacho Ribeiro v. Mexico, supra note 64; Nyaya v. Nepal, supra note 64 .
} 
Nepalese military. However, her criminal rape charges were not admitted because of a 35-day limitation for rape allegations. ${ }^{70}$ The Committee argued that the limitation period was unreasonably short and was thus 'flagrantly inconsistent with the gravity and nature of the crime and that it ha[d] a disproportionately negative effect on women, who are predominantly the victims of rape'. ${ }^{71}$ Similarly, in $X$ v. Sri Lanka, the author had been raped by two men. ${ }^{72}$ The Committee found a violation of Article 26 ICCPR because the respondent had failed to investigate the author's allegations properly. ${ }^{73}$

As the preceding analysis shows, the case law of the Committee tries to achieve two aims. On the one hand, it is directed against gender stereotypes, which are often expressed in social benefits legislation. ${ }^{74}$ Here, the assumption used to be that men are breadwinners of the family, while women were financially dependent on their husbands. By expressing these stereotypes, the legislation reinforces traditional gender roles. More recent cases are, rather, concerned with indirect discrimination, that is, with situations in which legislation seems to be neutral on its face but which predominantly disadvantage women. Short limitation statutes for rape or the failure to investigate rape allegations are not discriminatory on their face because they do not explicitly distinguish between different sexes. However, such practices severely disadvantage women. ${ }^{75}$ In its General Recommendations on violence against women, the Committee on the Elimination of Discrimination against Women (CEDAW) noted that 'gender-based violence against women is one of the fundamental social, political and economic means by which the subordinate position of women with respect to men and their stereotyped roles are perpetuated'. ${ }^{76}$ Similarly, the IACtHR has a long line of cases in which it finds discrimination because of gender-based violence. ${ }^{77}$ The case law of the HRC is in line with this practice: By qualifying gender-based violence not only as a violation of the physical integrity of the concerned women, but also as a violation of the non-discrimination guarantees in Articles 3 and 26 ICCPR, the Committee underlines the importance of specifically denouncing gender-based violence as an instrument of subordinating women.

\subsubsection{Citizenship}

The second category of cases deals with discrimination based on citizenship. ${ }^{78}$ While citizenship is not explicitly mentioned as a suspect criterion in Article 26 ICCPR, the provision refers to the related category of national origin. ${ }^{79}$ Principally, foreign citizens are a vulnerable group because they usually lack the right to vote and are thus underrepresented in the political process. ${ }^{80}$

This is reflected in the case law of the HRC. Gueye v. France concerned a Senegalese soldier who had served in the French army, but received a lower pension than his French colleagues. ${ }^{81}$ The Committee argued that nationality was a suspect classification that was similar to the ones which

\footnotetext{
${ }^{70}$ Purna Maya v. Nepal, ibid.

${ }^{71}$ Ibid., para. 12.5 .

${ }^{72} \mathrm{X}$ v. Sri Lanka, supra note 64.

${ }^{73}$ Ibid., para. 7.6 .

${ }^{74}$ On the need to counter the social construction of gender stereotypes see CESCR, General Comment No. 20: NonDiscrimination in Economic, Social and Cultural Rights (Art. 2, para. 2, of the International Covenant on Economic, Social and Cultural Rights), UN Doc. E/C.12/GC/20 (2009), para. 20.

${ }^{75}$ See Chinkin, supra note 63, paras. 19-22.

${ }^{76} \mathrm{CEDAW}$, General Recommendation No. 35 on Gender-Based Violence Against Women, updating General Recommendation No. 19, UN Doc. CEDAW/C/GC/35 (2017), para. 10.

${ }^{77}$ See, e.g., González et al. ('Cotton Field') v. Mexico, Judgment of 16 November 2009, [2009] IACHR (Ser. C), paras. 390402; Trabajadores de la hacienda Brasil verde v. Brasil, Judgment of 20 October 2016, [2016] IACHR (Ser. C), paras. 334-41; López Soto and Others v. Venezuela, Judgment of 26 September 2018, [2018] IACHR (Ser. C), paras. 210-20.

${ }^{78}$ Gueye et al. v. France, 3 April 1989, UN Doc. CCPR/C/35/D/196/1985; Simunek v. Czech Republic, 19 July 1995, UN Doc. CCPR/C/54/D/516/1992; Karakurt v. Austria, 4 April 2002, UN Doc. CCPR/C/74/D/965/2000.

${ }^{79}$ See also MacKean, supra note 2.

${ }^{80} \mathrm{Ely}$, supra note 10 , at 161 .

${ }^{81}$ Gueye v. France, supra note 78.
} 
were explicitly listed in Article $26 \mathrm{ICCPR}^{82}$ and that there was discrimination because the Senegalese soldiers had provided the same services as their French counterparts. ${ }^{83}$ France had argued that the difference in treatment was justified because the living expenses were much higher in France than in Senegal. However, the Committee rejected this argument because the living expenses were tied to the country of residence not to the citizenship so that the distinction was unreasonable. ${ }^{84}$

Many cases in this category concerned Czech restitution legislation that was enacted after 1990 and concerned expropriations during the Communist era. ${ }^{85}$ The Czech legislation required that individuals entitled to restitution or compensation had to have Czech citizenship and residence within the Czech Republic or Slovakia. Many dissidents had fled Czechoslovakia during the Communist era and had been stripped of their citizenship. The legislation, therefore, excluded predominantly the victims of political persecution from its scope. Consequently, the Committee found that the citizenship requirement amounted to unjustified discrimination. ${ }^{86}$

\subsubsection{Sexual orientation and gender identity}

A more recent category of cases concerns discrimination based on sexual orientation or of transgender individuals. ${ }^{87}$ Neither sexual orientation nor gender identity is explicitly mentioned as a suspect criterion in Article 26 ICCPR. Nevertheless, both homosexual and transgender individuals have, for a long time, been subject to discrimination. Negative stereotypes against these two groups still prevail in many societies today. Therefore, sexual orientation and gender identity are now widely recognized as suspect criteria. $^{88}$

Nevertheless, the HRC was initially reluctant to recognize sexual orientation as a suspect criterion. In Joslin v. New Zealand, the Committee held that denying same-sex couples the right to get married did not amount to discrimination under Article 26 ICCPR. ${ }^{89}$ However, the right to marriage may have been a special case because it is politically a highly sensitive issue. The HRC is not the only international human rights body denying such a right to same-sex couples, as there are similar decisions of the ECtHR. ${ }^{90}$

\footnotetext{
${ }^{82}$ Ibid., para. 9.4.

${ }^{83}$ Ibid., para. 9.5 .

${ }^{84} \mathrm{Ibid}$.

${ }^{85}$ Simunek v. Czech Republic, supra note 78; Adam v. Czech Republic, 23 July 1996, UN Doc. CCPR/C/57/D/586/1994; Blazek v. Czech Republic, 12 July 2001, UN Doc. CCPR/C/72/D/857/1999; Des Fours Walderode v. Czech Republic, 30 October 2001, UN Doc. CCPR/C/73/D/747/1997; Marik v. Czech Republic, 26 July 2005, UN Doc. CCPR/C/84/D/945/ 2000; Kriz v. Czech Republic, 18 November 2005, UN Doc. CCPR/C/85/D/1054/2002; Polackova v. Czech Republic, 24 July 2007, UN Doc. CCPR/C/90/1445/2006; Gratzinger v. Czech Republic, 25 October 2007, UN Doc. CCPR/C/91/D/ 1463/2006; Ondracka v. Czech Republic, 31 October 2007, UN Doc. CCPR/C/91/D/1533/2006; Süsser v. Czech Republic, 25 March 2008, UN Doc. CCPR/C/92/D/1488/2006; Lnenicka v. Czech Republic, 25 March 2008, UN Doc. CCPR/C/92/ D/1484/2006; Vlcek v. Czech Republic, 10 July 2008, UN Doc. CCPR/C/93/D/1485/2006; Preiss v. Czech Republic, 17 July 2008, UN Doc. CCPR/C/93/D/1497/2006; Kohoutek v. Czech Republic, 17 July 2008, UN Doc. CCPR/C/93/1448/2006; Amundson v. Czech Republic, 17 March 2009, UN Doc. CCPR/C/95/D/1508; Persan v. Czech Republic, 24 March 2009, UN Doc. CCPR/C/95/D/1479/2006; Slezák v. Czech Republic, 20 July 2009, UN Doc. CCPR/C/96/D/1574/2007; Drda v. Czech Republic, 27 October 2010, UN Doc. CCPR/C/100/D/1581/2007.

${ }^{86}$ Simunek v. Czech Republic, supra note 78, para. 11.6.

${ }^{87}$ Young v. Australia, 6 August 2003, UN Doc. CCPR/C/78/D/941/2000; X v. Colombia, 30 March 2007, UN Doc. CCPR/C/ 89/D/1361/2005; G v. Australia, 17 March 2017, UN Doc. CCPR/C/119/D/2172/2012; C v. Australia, 28 March 2017, UN Doc. CCPR/C/119/D/2216/2012.

${ }^{88}$ See the jurisprudence of the ECHR and the IACHR, supra notes 8 and 9. See further CESCR, General Comment No. 20, supra note 74, para. 32; UN Committee against Torture, General Comment No. 2: Implementation of article 2 by State parties, UN Doc. CAT/C/GC/2 (2008), para. 21; CEDAW, General Recommendation No. 27 on older women and protection of their human rights, UN Doc. CEDAW/C/GC/27 (2010), para. 13.

${ }^{89}$ Joslin v. New Zealand, 17 July 2002, UN Doc. CCPR/C/75/D/902/1999.

${ }^{90}$ See Rees $v$ United Kingdom, Judgment of 17 October 1986, [1986] ECHR (Ser. A), no. 106; Schalk and Kopf v. Austria, Judgment of 24 June 2010, [2010] ECHR 2010-IV, at 409.
} 
Only one year after Joslin, the Committee became more accommodating towards discrimination based on sexual orientation. It held that Australian social benefits legislation, which granted a veteran pension only to the surviving partner of a heterosexual relationship, but not of a homosexual relationship, amounted to discrimination based on sexual orientation. ${ }^{91}$ Another case brought against Australia targeted divorce legislation, which did not allow for divorce proceedings for a same-sex marriage concluded abroad. ${ }^{92}$ The Committee found that the Australian legislation was inconsistent: While it generally allowed for the divorce of marriages not recognized in Australia (such as polygamous marriages), it made an explicit exception for same-sex marriages and thus constituted discrimination based on sexual orientation. ${ }^{93}$

A final case against Australia involved discrimination against transgender individuals. In $G \mathrm{v}$. Australia, the author wanted to change the sex in her birth certificate from male to female. As she was married to a woman, this request was denied in order to preserve the status of marriage as an institution for heterosexual couples. ${ }^{94}$ The HRC argued that the prohibition of discrimination in Article 26 ICCPR encompassed discrimination based on transgender status ${ }^{95}$ and found the legislation in question to be inconsistent: Australia allowed the change of sex in passports and other identity documents and recognized the change of status in a foreign country even after marriage so that it was unreasonable to deny such a change in birth certificates. ${ }^{96}$

\subsubsection{Political opinion}

A significant number of cases, in which the HRC found a violation of Article 26 ICCPR concerned discrimination based on political opinion, which is explicitly mentioned as a suspect criterion in Article 26 ICCPR. ${ }^{97}$ These cases predominantly concerned individuals who were harassed or persecuted because of their opposition to the government. In most of these cases, the main emphasis of the analysis lay on different provisions of the Covenant, such as Articles 7, 9 or Article 25 ICCPR. The Committee only mentioned the discrimination based on political opinion according to Article 26 ICCPR in addition to the other violations in order to emphasize the severity of the violation.

In Oló Bahamonde, the authors were arbitrarily detained and harassed by the government of Equatorial Guinea because of their opposition to the president. ${ }^{98}$ The Committee found primarily violations of the right to liberty and security (Article 9 ICCPR), the freedom of movement (Article 12 ICCPR), and the right of equality before courts and tribunals (Article 14(1) ICCPR). ${ }^{99}$ However, it also held that Article 26 ICCPR had been violated because the author had been harassed because of his opposition to the government. ${ }^{100}$ In Sudalenko, Belarus had denied registering the author for elections to the House of Representatives. ${ }^{101}$ Furthermore, the latter suffered several reprises for his political activism. In its reasoning, the Committee was primarily concerned with the right to be elected and to take part in public affairs guaranteed by Article 25 ICCPR. ${ }^{102}$ In passing, the

\footnotetext{
${ }^{91}$ Young v. Australia, supra note 87.

${ }^{92} \mathrm{C}$ v. Australia, supra note 87.

${ }^{93}$ Ibid., para. 8.6.

${ }^{94} G$ v. Australia, supra note 87.

${ }^{95}$ Ibid., para. 7.12.

${ }^{96}$ Ibid., paras. 7.7-7.8, 7.14.

${ }^{97}$ Bwalya v. Zambia, 14 July 1993, UN Doc. CCPR/C/48/D/314/1988; Orihuela Valenzuela v. Peru, 14 July 1993, UN Doc. CCPR/C/48/D/309/1988; Oló Bahamonde v. Equatorial Guinea, 20 October 1993, UN Doc. CCPR/C/49/D/468/1991; Korneenko v. Belarus, 20 March 2009, UN Doc. CCPR/C/95/D/1553/2007; Sudalenko v. Belarus, 19 October 2010, UN Doc. CCPR/C/100/D/1354/2005; Umarova v. Uzebkistan, 19 October 2010, UN Doc. CCPR/C/100/D/1449/2006; MT v. Uzbekistan, 23 July 2015, UN Doc. CCPR/C/114/D/2234/2013.

${ }^{98}$ Oló Bahamonde, ibid., at 97.

${ }^{99}$ Ibid., paras. 9.2-9.4

${ }^{100}$ Ibid., para. 9.5 .

${ }^{101}$ Sudalenko v. Belarus, supra note 97.

${ }^{102}$ Ibid., paras. 6.4-6.7.
} 
Committee simply stated that Belarus' conduct also violated Article 26 ICCPR. ${ }^{103}$ Finally, in MT v. Uzbekistan, the author, a female human rights activist, was gang-raped and forcefully sterilized. ${ }^{104}$ The main emphasis of the analysis lay on the violation of the prohibition of torture in Article 7 ICCPR. ${ }^{105}$ But the Committee also found a violation of Article 26 ICCPR because of discrimination based on both sex and political opinion. ${ }^{106}$

\subsubsection{Race}

Racial discrimination is not only explicitly prohibited by Article 26 ICCPR, but has been specifically outlawed by the International Convention on the Elimination of All Forms of Racial Discrimination. ${ }^{107}$ Furthermore, it has been a significant concern in the constitutional jurisprudence of many jurisdictions, in particular the jurisprudence of the US Supreme Court. ${ }^{108}$ Yet, there is only one individual communication in which the HRC found a violation of Article 26 ICCPR exclusively because of racial discrimination. ${ }^{109}$ In Williams Lecraft, the author was singled out for an identity check by the police because of her skin colour. ${ }^{110}$ The Committee held this form of racial profiling to be racial discrimination because the author had been selected for the check exclusively because of her race. ${ }^{111}$

\subsubsection{Other suspect criteria}

There are a few cases, in which the HRC found discrimination based on other suspect criteria, most of which are explicitly recognized by Article 26 ICCPR. In Waldman v. Canada, the respondent had discriminated based on religion because the Province of Ontario had only provided financial support for Roman-Catholic schools, but not for private schools of other religious denominations. ${ }^{112}$ In Derksen, the Netherlands had discriminated against children born out of wedlock because it provided financial support to half-orphans only in cases in which the parents had been married. ${ }^{113}$

In Haraldsson and Sveinsson, the authors challenged a fishing quota that was initially distributed for free according to the actual fishing quotas in 1980 to 1983, which were then perpetuated. ${ }^{114}$ Subsequent fishers who wanted to get a fishing quota had either to buy or to lease them from one of the legacy fishers. The HRC held that the distinction in question between legacy fishers and those without previous quota rights amounted to a distinction based on property. ${ }^{115}$ As it entrenched existing advantages without proper justification instead of redistributing them based on more objective criteria, the measure was not justified. ${ }^{116}$

In several cases against France, the HRC found discrimination based on conscience because conscientious objectors had to serve twice as long in social services than individuals serving in

\footnotetext{
${ }^{103}$ Ibid., para. 6.7.

${ }^{104} M T$ v. Uzbekistan, supra note 97.

${ }^{105}$ Ibid., paras. 7.2-7.5.

${ }^{106}$ Ibid., para. 7.6.

${ }^{107}$ UNTS 660, at 1 . On attempts in international law to combat racial discrimination see, generally, T. von Boven, 'Racial and Religious Discrimination', in R. Wolfrum (ed.), Max Planck Encyclopedia of Public International Law (2007).

${ }^{108}$ See R. B. Siegel, 'From Colorblindness to Antibalkanization: An Emerging Ground of Decision in Race Equality Cases', (2011) 120 Yale Law Journal 1278.

${ }^{109}$ Williams Lecraft v. Spain, 27 July 2009, UN Doc. CCPR/C/96/D/1493/2006. But see also X v. Sri Lanka, supra note 64, where the Committee found discrimination based on both gender and ethnicity.

${ }^{110}$ Williams Lecraft v. Spain, supra note 109.

${ }^{111}$ Ibid., para. 7.4.

${ }^{112}$ Waldman v. Canada, 3 Nov. 1999, UN Doc. CCPR/C/67/D/694/1996, para. 10.6.

${ }^{113}$ Derksen v. the Netherlands, 1 April 2004, UN Doc. CCPR/C/80/D/976/2001, para. 9.3.

${ }^{114}$ Haraldsson and Sveinsson v. Iceland, 24 October 2007, UN Doc. CCPR/C/91/D/1306/2004.

${ }^{115}$ Ibid., para. 10.3 .

${ }^{116}$ Ibid., para. 10.4 .
} 
the military. While conscience is not explicitly recognized in Article 26 ICCPR, Article 18 ICCPR highlights its close connection to the concept of religion, which is explicitly recognized as a suspect criterion under Article 26 ICCPR. ${ }^{117}$

In $Q$ v. Denmark, the Committee dealt with discrimination based on disability during a citizenship application. ${ }^{118}$ Disability is not a characteristic explicitly mentioned in Article 26 ICCPR. However, there is a long history of disrespect against individuals with disabilities. ${ }^{119}$ Therefore, disability is widely regarded as a suspect criterion today. ${ }^{120}$ This is also underlined by the adoption of the UN Convention on the Rights of Persons with Disabilities, ${ }^{121}$ which recognizes and specifically protects individuals with disabilities. In the individual communication before the HRC, the author had applied for Danish citizenship. He had asked for an exemption from the language proficiency test for medical reasons because he suffered from a severe chronic mental disorder. Even though he submitted an expert opinion detailing the grounds for the exemption request, his request was denied without reasons. The Committee argued that the administrative decision discriminated based on disability ${ }^{122}$ and was not justified because it failed to demonstrate that the refusal to grant the exemption was based on reasonable and objective grounds. ${ }^{123}$

Finally, the case of Diergaardt illuminates the dangers of an overly schematic focus on suspect criteria. The case deals with the treatment of an Afrikaans community in Namibia. The authors were members of the concerned community, which had enjoyed a great deal of autonomy since it had settled on the territory of present-day Namibia. The community was deprived of its autonomy after Namibia's independence and sought legal protection in Namibia's courts. In their dealings with the administrative authorities and judicial bodies, its members were forced to use English, the official language of Namibia, in all communications even though they were not fluent in it. The HRC referred to a government circular, which instructed civil servants not to use Afrikaans in their official communications, and concluded that the state intentionally targeted Afrikaans speakers which amounted to a violation of Article 26 ICCPR.

Language is explicitly mentioned as a problematic characteristic in Article 26 ICCPR. It is a suspect criterion because linguistic minorities are potentially vulnerable groups. However, not every distinction based on a suspect criterion necessarily amounts to unjustified discrimination. As is pointed out in some of the individual opinions, English was introduced in Namibia as the exclusive official language in order not to give preference to any of the tribal languages. The specific instruction of the government not to use Afrikaans was related to the fact that Afrikaans used to be the official language prior to independence so that many administrative officials could speak and read the language. Instead of disadvantaging Afrikaans speakers, the instruction rather intended to create a level playing field: Afrikaans speakers should not be treated more favourably than the speakers of any of the tribal languages. Consequently, while language is explicitly mentioned in Article 26 ICCPR, the Afrikaans community in Diergaardt hardly qualifies as a vulnerable group because it relied on the previously privileged position of its native language. Therefore,

\footnotetext{
${ }^{117}$ See Moeckli, supra note 2, at 163 (arguing that 'conviction' is a suspect classification); S. Joseph and M. Castan, The International Covenant on Civil and Political Rights: Cases, Materials, and Commentary (2013), 786; Nowak, supra note 4, Art. 26, paras. 28-33 (discussing conscience and religion in the same category). See also Bayefski, supra note 2, at 19 (arguing that the protection against discrimination based on religion deserves particular attention).

${ }^{118}$ Q v. Denmark, 1 April 2015, UN Doc. CCPR/C/113/D/2001/2010.

${ }^{119}$ See Committee on the Rights of Persons with Disabilities (CRPD), General Comment No. 6 on equality and non-discrimination, UN Doc. CRPD/C/GC/6 (2018), para. 7.

${ }^{120}$ See T. Degener, 'Disabled People, Non-Discrimination of, in R. Wolfrum (ed.), Max Planck Encyclopedia of Public International Law (2019), para. 3; Craven, supra note 2, at 170. See further CESCR, General Comment No. 20, supra note 74, para. 28; CAT, General Comment No. 2, supra note 88, para. 21; CRPD, General Comment No. 6, supra note 119.

${ }^{121}$ UNTS 2515 , at 3.

${ }^{122}$ Ibid., para. 7.3 .

${ }^{123}$ Ibid., para. 7.5 .
} 
it is not surprising that the case was highly controversial, with six Committee members writing dissenting individual opinions. ${ }^{124}$

\subsection{Violations of equality outside suspect classifications}

There are a handful of cases in which the Committee found a violation of Article 26 ICCPR even though the challenged distinctions were not based on suspect criteria. The majority of these cases arguably target arbitrary state action. ${ }^{125}$ While arbitrariness was explicitly mentioned as a necessary precondition for finding discrimination in Pohl and some subsequent cases, ${ }^{126}$ the Committee has been inconsistent in resorting to the concept of arbitrariness and has not developed it in its case law. Furthermore, the Committee has only mentioned arbitrariness in cases in which it finally did not consider state action to be arbitrary. By contrast, the cases that actually do find an arbitrary practice to be in violation of Article 26 ICCPR do not mention the concept of arbitrariness explicitly.

Nevertheless, the administrative and legislative practice that is reviewed in some individual communications can, arguably, only be classified as arbitrary. ${ }^{127}$ In Fábryová, the Committee had to deal with an administrative decision denying the author restitution for expropriation during communist rule. ${ }^{128}$ It held that the decision against the author amounted to unequal treatment because other individuals in comparable situations to the author had received compensation. ${ }^{129}$ An administrative appeal to the decision had conceded that the original decision was wrong, but was not recognized by the state party because it had been issued too late, even though the late decision was fully attributable to the fault of the authorities. ${ }^{130}$

In Blaga, the Committee found that a decision of the Romanian Supreme Court had violated Article 26 ICCPR because it had quashed a decision of the Court of Appeals allowing the authors restitution of their property even though the latter decision had already become final before it was challenged by the state. ${ }^{131}$ Finally, Kavanagh concerned the competence of the Irish public prosecutor to prosecute in special courts with particular procedural rules if at least one of the prosecuted defences was contained in a list of crimes related to terrorism. The Committee argued that this procedural setting violated Article 26 ICCPR because the prosecutor had unfettered discretion in its choice of the appropriate criminal procedure and did not need to justify its decision. ${ }^{132}$

Certainly, arbitrariness is an elusive concept. We can approach the concept from two vantage points. In a primary sense, arbitrary decisions are decisions that are not grounded in reason or principle. In this sense, arbitrary would be identical with lacking a reasonable and objective justification, ${ }^{133}$ i.e., precisely the formula that the HRC uses in its justification analysis. The problem with this understanding has already been pointed out: Whether a specific decision is reasonable, is often in the eye of the beholder. ${ }^{134}$ There can be reasonable disagreement on whether a specific state action is indeed reasonable. ${ }^{135}$

\footnotetext{
${ }^{124}$ On the controversial nature of the case, see Nowak, supra note 4, para. 35.

${ }^{125}$ Kavanagh v. Ireland, 4 April 2001, UN Doc. CCPR/C/71/D/819/1998; Fábryová v. Czech Republic, 30 October 2001, UN Doc. CCPR/C/73/D/765/1997; Pezeldova v. Czech Republic, 25 October 2002, UN Doc. CCPR/C/76/D/757/1997; Blaga v. Romania, 24 April 2006, UN Doc. CCPR/C/86/D/1158/2003.

${ }^{126}$ Pohl v. Austria, supra note 41, para. 9.3; Jongenburger-Veerman v. the Netherlands, supra note 44, para. 7.2; O’Neill and Quinn v. Ireland, supra note 46, para. 8.4. See also supra, text accompanying notes 41-7.

${ }^{127}$ See Edelenbos, supra note 4 , at $80-1$.

${ }^{128}$ Fábryová v. Czech Republic, supra note 125.

${ }^{129}$ Ibid., para. 9.2.

${ }^{130}$ Ibid.

${ }^{131}$ Blaga v. Romania, supra note 125 , para. 10.2 .

${ }^{132}$ Kavanagh v. Ireland, supra note 125 , para. 10.2 .

${ }^{133}$ See R. Uprimny Yepes and L. M. Sánchez Duque, 'Artículo 24: Igualdad ante la ley', in C. Steiner and P. Uribe (eds.), Convención Americana sobre Derechos Humanos (2014), 579, at 587.

${ }^{134}$ See above, at Section 3.4.

${ }^{135}$ On the concept of reasonable disagreement see S. Besson, The Morality of Conflict. Reasonable Disagreement and the Law (2005).
} 
There is a second understanding of arbitrariness as an indication of the standard of review and the degree of deference a court pays to the legislature or the executive. In this sense, it denominates the loosest standard of review that a court can apply in equality cases. The rational basis test of the U.S. Supreme Court, which is supposed to weed out arbitrary state action, only finds violations of equal protection in rare cases. ${ }^{136}$ Similarly, the German Federal Constitutional Court has an arbitrariness review standard (Willkürkontrolle) as its most restrained standard of review in equality cases. ${ }^{137}$ In this understanding, arbitrary state action refers to cases in which the unreasonableness is obvious, i.e., where there is no reasonable disagreement at least among legal experts.

The three discussed cases of the HRC arguably fall into this latter category. Fábryová is a textbook case of arbitrariness because different individuals are treated differently without any discernible reason, while the other two cases violate well-respected rule-of-law principles. Arbitrariness is thus a residual category reserved for cases in which no suspect classification is involved, but where the injustice is so egregious that the Committee nevertheless wants to exercise a corrective function.

\subsection{Individual communications finding no violation of equality}

The preceding discussion has only shown one side of the coin: We have seen that the presence of a suspect criterion of distinction is almost a necessary condition for the HRC to find a violation of Article 26 ICCPR or an equivalent non-discrimination norm under the Covenant. However, is it also a sufficient condition, that is, does the Committee always find a violation, if a suspect criterion or arbitrary state action can be shown? A cursory glance seems to answer the question in the negative: If a claim of discrimination was based on a suspect criterion, the Committee found a violation only in roughly 60 per cent of all cases in our analysis (31 out of 53).

Yet, if we take a closer look at the cases in which a suspect criterion was present but no violation found, we can explain most of them if we look at additional predictors. First, there are a number of cases in which the criterion of distinction was arguably suspect but the Committee makes it easier for the state to justify such distinctions than for other suspect characteristics. These concern in particular distinctions based on marriage, age and residence.

In contrast to criteria like sex or race, one can reasonably debate whether marriage, age and residence should be considered suspect criteria at all. One can make the case that marriage is a suspect criterion because married individuals traditionally experience much more social respect than non-married individuals. In particular, unmarried women suffer from social stigma in many societies even today. For this reason, the HRC has stressed the necessity to respect various forms of families on an equal basis, regardless of marriage, in its General Comment No. 28. ${ }^{138}$ Nevertheless, in its individual communications, the Committee usually considered marriage to be a choice of the couple that justifies favourable treatment for married couples compared to unmarried ones. ${ }^{139}$

Residence is another characteristic whose suspectness is debatable. ${ }^{140}$ Like citizenship rules, residence requirements may also target outsiders without political influence in the decisionmaking process. Nevertheless, the Committee considered residence requirements as a

\footnotetext{
${ }^{136}$ See K. Yoshino, 'Why the Courts Can Strike down Marriage Restrictions under Rational Basis Review', (2013) 37 NYU Review of Law \& Social Change 331, at 333; R. Holoszyc-Pimentel, 'Reconciling Rational Basis Review: When Does Rational Basis Bite?', (2015) 90 New York University Law Review 2070, at 2071; Chemerinsky, supra note 22, at 402.

${ }^{137}$ See L. Osterloh, 'Der Gleichheitssatz zwischen Willkürverbot und Grundsatz der Verhältnismäßigkeit', in C. Franzius et al. (eds.), Beharren. Bewegen. Festschrift für Michael Kloepfer zum 70. Geburtstag (2013), at 139; Petersen, supra note 21, at 339-45.

${ }^{138}$ HRC, General Comment No. 28: Article 3 (The equality of rights between men and women), UN Doc. HRI/GEN/1/Rev.9 (2000), para. 27.

${ }^{139}$ Danning $v$. the Netherlands, supra note 23; Sprenger v. the Netherlands, 31 March 1992, UN Doc. CCPR/C/44/D/395/ 1990; Snijders et al. v. the Netherlands, 27 July 1998, UN Doc. CCPR/C/63/D/651/1995; Hoofdman v. the Netherlands, 3 November 1998, UN Doc. CCPR/C/64/D/602/1994.

${ }^{140}$ See, e.g., CESCR, General Comment No. 20, supra note 74, para. 34 (classifying residence as a suspect criterion).
} 
precondition for voting rights to be justifiable. ${ }^{141}$ Finally, age is a criterion that is often considered to be suspect. ${ }^{142}$ Accordingly, the HRC has recognized age to be a status of distinction under Article 26 ICCPR. ${ }^{143}$ Nevertheless, it has never found age discrimination to be a violation of the Covenant. ${ }^{144}$

If we examine the remaining cases in which the distinction was supposedly based on a suspect criterion, many of these cases concerned indirect discrimination in which the challenged distinction was not explicitly based on a suspect characteristic. Even though the authors of the individual communications claimed that there was a disparate impact on a group defined by one of the suspect criteria, the Committee has been hesitant to acknowledge indirect discrimination. It usually argued that there was no sufficient proof for such a disparate impact or sometimes even flatly denied the problem. ${ }^{145}$ Finally, the Committee has repeatedly welcomed affirmative action as a justification for discrimination in its General Comments. ${ }^{146}$ Accordingly, the Committee considered a gender quota for the Belgian High Court of Justice to be justified because it was qualified as affirmative action for women. ${ }^{147}$

Certainly, these additional predictors do not explain the totality of the case law. There are still a few cases in which the Committee did not find a violation of Article 26 ICCPR despite a suspect criterion of distinction and which are also not explained by the additional predictors discussed above. ${ }^{148}$ One of them is the already mentioned Järvinen case, ${ }^{149}$ which has been overturned in Foin. ${ }^{150}$ Another is the decision on same sex marriage in Joslin, which was politically sensitive. ${ }^{151}$ Overall these cases are exceptions which amount to less than 10 per cent of all cases involving a suspect classification (four out of 53).

\section{Conclusions}

This article has shown a considerable gap between the doctrinal formulae that the HRC has developed in order to operationalize equality and non-discrimination norms of the Covenant and the actual practice that is reflected in its individual communications. This inconsistency is not surprising given the vague nature of the Committee's objective-and-reasonable-criteria formula and the insufficient development of further specifications.

However, if we look at the actual practice of the Committee, we can find a rather stable pattern. In the first part of this study, we have identified two archetypes of the equality and non-

\footnotetext{
${ }^{141}$ Gillot et al. v. France, 15 July 2002, UN Doc. CCPR/C/75/D/932/2000.

${ }^{142}$ See S. Ruppert and K. Lovric-Pernak, 'Age Discrimination', in R. Wolfrum, Max Planck Encyclopedia of Public International Law (2011).

${ }^{143}$ Love et al. v. Australia, 25 March 2003, UN Doc. CCPR/C/78/D/983/2001, para. 8.2.

${ }^{144}$ Schmitz-de-Jong v. the Netherlands, 16 July 2001, UN Doc. CCPR/C/72/D/855/1999; Love et al. v. Australia, supra note 143.

${ }^{145}$ See Singh-Bhinder v. Canada, 9 November 1989, UN Doc. CCPR/C/37/D/208/1986; Oulajin and Kaiss v. the Netherlands, supra note 51; Brinkhof v. the Netherlands, 27 July 1993, UN Doc. CCPR/C/48/D/402/1990; Cavalcanti Araujo-Jongen v. the Netherlands, 22 October 1993, UN Doc. CCPR/C/49/D/418/1990; Pepels v. the Netherlands, 15 July 1994, UN Doc. CCPR/C/51/484/1991; Toala et al. v. New Zealand, 2 November 2000, UN Doc. CCPR/C/70/D/675/1995; Baumgarten v. Germany, 31 July 2003, UN Doc. CCPR/C/78/D/960/2000; Prince v. South Africa, 31 October 2007, UN Doc. CCPR/C/91/D/1474/2005; Kalevi Paadar et al. v. Finland, 26 March 2014, UN Doc. CCPR/C/110/D/2102/2011; Mohamed Rabbae et al. v. the Netherlands, 14 July 2016, UN Doc. CCPR/C/117/D/2124/2011.

${ }^{146}$ See, generally, HRC, General Comment No. 18, supra note 29, para. 10, and General Comment No. 28, Article 3 (The equality of rights between men and women), UN Doc. CCPR/C/21/Rev.1/Add.10 (2000), para. 3 (specifically for measures regarding the 'effective and equal empowerment of women').

${ }^{147}$ Jacobs $v$. Belgium, supra note 30.

${ }^{148}$ Vos v. the Netherlands, 26 July 1999, UN Doc. CCPR/C/66/786/1997; Delgado Páez v. Colombia, 12 July 1990, UN Doc. CCPR/C/39/D/195/1985; Järvinen v. Finland, supra note 31; Joslin v. New Zealand, supra note 89. For a critique of Vos, see Bayefski, supra note 2, at 15.

${ }^{149}$ Järvinen $v$. Finland, supra note 31.

${ }^{150}$ Foin v. France, supra note 34.

${ }^{151}$ See above, at Section 4.1.3.
} 
discrimination jurisprudence - the equality-as-non-discrimination approach and the equality-asconsistency approach. The case law of the HRC rather resembles the former because the existence of a suspect criterion of distinction is the most important predictor for finding a violation of an equality norm under the Covenant. Nevertheless, the mere existence of a distinction based on a suspect classification is no sufficient condition for finding a violation. Instead, the Committee is reluctant to find violations in cases of indirect discrimination and allows for justifications in cases of affirmative action. If a suspect criterion of distinction is absent, the Committee rarely finds a violation of Article 26 ICCPR. The few cases, in which the HRC did find a violation in the absence of a suspect criterion concerned arbitrary legislative or administrative action, in which the unreasonableness was obvious.

There is certainly potential to criticize the jurisprudence of the HRC. The concept of arbitrariness remains under-specified, and the approach to indirect discrimination is woefully under-complex. Nevertheless, the basic approach seems to be a reasonable basis for conceptualizing equality under the ICCPR. However, one urgent task remains: The HRC should bring the formulae specifying its equality doctrine in line with its actual practice. This does not require a revolution as the seeds of such a doctrine have already been spelled out in Pohl and some subsequent cases. ${ }^{152}$ The Committee would only need to apply this formula more consistently and progressively develop it to address the remaining deficiencies.

\footnotetext{
${ }^{152}$ Pohl v. Austria, supra note 41, para. 9.3; Jongenburger-Veerman v. the Netherlands, supra note 44, para. 7.2; O'Neill and Quinn v. Ireland, supra note 46, para. 8.4. See also supra, text around notes 41-7.

Cite this article: Petersen N (2021). The implicit taxonomy of the equality jurisprudence of the UN Human Rights Committee. Leiden Journal of International Law 34, 421-440. https://doi.org/10.1017/S092215652100008X
} 